\title{
В.К. ОКУЛИЧ
}

\section{АБЗИМНАЯ АКТИВНОСТЬ ИММУНОГЛОБУЛИНОВ ПРИ ХИРУРГИЧЕСКОЙ ИНФЕКЦИИ}

\author{
УО «Витебский государственный медицинский университет», \\ Республика Беларусь
}

Цель. Определить роль протеолитической, ДНКазной, эскулиназной и уреазной активности абзимов в клинико-лабораторной картине и оценить их способность расщеплять экзополимерный матрикс биопленок у пациентов с хирургической инфекцией.

Материал и методы. Все пациенты, у которых определялась абзимная активность, были разделены на группы: группа лиц с хроническими гнойно-воспалительными процессами, пациенты с распространенными острыми гнойно-воспалительными процессами, лица с локальными острыми гнойно-воспалительными процессами, гнойно-воспалительными заболеваниями челюстно-лицевой области, хроническим остеомиелитом, холециститом, узловым зобом, гастродуоденитом и тяжелой пневмонией. Контрольную группу составили доноры станции переливания крови и пациенты без гнойно-воспалительных процессов. Определена протеолитическая активность иммуноглобулинов $\mathrm{G}$ пациентов с хирургической инфекцией и здоровых доноров в реакциях с хромогенными субстратами: бензоил-аргинин-р-нитроанилидом (БАПНА), лизин-р-нитроанилидом (ЛНА), аргинин-пролин-р-нитроанилидом (АПНА) и ацетил-аспартат-р-нитроанилидом (ААНА).

Результаты. Установлено, что у пациентов с хирургической инфекцией уровень БАПНА-амидазной активности был достоверно выше, ЛНА- и АПНА-амидазной не отличался, а ААНА-амидазной был достоверно ниже, чем у доноров. Обнаружено, что иммуноглобулины, выделенные от пациентов с хирургической инфекцией, обладают способностью разрушать экзополимерный матрикс биопленки. Выявлено наличие достоверно повышенного уровня ДНКазной и эскулиназной активности IgG у пациентов хирургического профиля с гнойно-воспалительными процессами в сравнении с пациентами без гнойных осложнений. Обнаружено наличие достоверной положительной связи средней силы между видом возбудителя гнойного процесса и ДНКазной активностью IgG. Показан повышенный уровень уреазной активности IgG, выделенных от пациентов с геликобактерными гастродуоденитами, в сравнении с лицами без геликобактерной инфекции.

Заключение. Полученные данные о каталитической активности IgG у лиц с инфекционным процессом могут быть использованы для разработки новых диагностических критериев и методов прогнозирования развития гнойно-воспалительных заболеваний.

Ключевые слова: хирургическая инфекиия, каталитические антитела, абзимы, биопленка, протеолитическая активность, диагностика критерии, гнойно-восполительные заболевания

Objectives. To determine the role of proteolytic, DNAse, esculinase and urease activity of abzymes in clinical and laboratory picture and to assess the capacity to destroy exopolymeric matrix of biofilms in patients with surgical infection.

Methods. All the patients tested for abzyme activity were divided into the following groups: a group of persons with various chronic inflammatory processes; with spreading inflammatory processes; persons with local acute inflammatory processes, pyoinflammatory disease of the maxillofacial area, chronic osteomyelitis, cholecystitis, adenomatous goiter, gastroduodenitis and severe form of pneumonia. Control group consisted of donors of blood transfusion station and patients without pyoinflammatory processes. Proteolytic activity of immunoglobulin G in reactions with chromogenic substrates: benzoyl-arginine-p-nitroanilide (BAPNA), lysine-p-nitroanilide (LPA), arginine-proline-p-nitroanilide (APNA) and acetyl-aspartate-p-nitroanilide (AANA) was determined in patients with surgical infection and healthy donors.

Results. It was found out that the rate of BAPNA-amidase abzyme activity in patients with surgical infection was reliably higher, LPA- and APNA-amidase rate didn't differ and AANA-amidase rate was significantly lower than in donors. It was revealed that immunoglobulins derived from patients with surgical infection have the ability to destroy the exopolymeric matrix of the biofilm. Presence of reliably elevated levels of DNAse and esculinase activity of IgG in surgical patients with pyo-inflammatory processes in comparison with patients without suppurative complications was determined. Positive reliable correlation between type of causative agent and DNAse activity of $\mathrm{IgG}$ was revealed. The elevated levels of urease activity of $\mathrm{IgG}$, derived from patients with gastroduodenitis, associated with $\mathrm{H}$. pylori in comparison with patients without $\mathrm{H}$. pylori infection was shown.

Conclusion. Obtained data concerning catalytic activity of $\mathrm{IgG}$ in patients with infectious process may be used for development of new diagnostic criteria and methods for prognosis of pyoinflammatory diseases.

Keywords: surgical infection, catalytic antibodies, abzymes, biofilm, proteolytic activity, diagnostic criteria, pyoinflammatory diseases

Novosti Khirurgii. 2016 Nov-Dec; Vol 24 (6): 568-578

Abzyme Activity of Immunoglobulins in Surgical Infection

V.K. Okulich 


\section{Введение}

Проблема лечения и профилактики инфекционных заболеваний является одной из приоритетных в здравоохранении. На современном этапе отмечено изменение клинической симптоматики и течения хирургической инфекции, что проявляется в увеличении числа тяжело протекающих и не поддающихся стандартному лечению осложненных форм гнойных заболеваний, удлинении сроков лечения, особенно на госпитальном этапе, учащении случаев стертых форм и атипичного течения хирургической инфекции [1].

Начиная с середины 80-х годов 20 века сформировалась новая область иммунологии, посвященная исследованию собственной каталитической активности иммуноглобулинов. Первые упоминания о такой активности появляются в литературных источниках,уже начиная с 60-х годов [2].

Иммуноглобулины с ферментными свойствами получили название абзимы (от английской аббревиатуры antibody-enzyme) или каталитически активные антитела [3]. За прошедшее время был накоплен значительный объем материала по этой тематике [2, 4]. Тем не менее, биологическая и патогенетическая роль каталитических антител к настоящему времени остается понятной не до конца. Большинство авторов в своих работах указывают на негативную роль абзимов в патогенезе различных заболеваний, но в ряде работ указывается на возможное протективное действие каталитических антител [5, 6, 7].

При взаимодействии макроорганизма с инфекционным агентом происходит массивная стимуляция иммунной системы антигенами микроорганизмов, в том числе его ферментами. При этом, согласно теории иммунных сетей Йерне, по механизму идиотип-антиидиотипического взаимодействия или имитации активными центрами антител переходных состояний соответствующих химических реакций, возможно образование антител с собственной каталитической активностью [8].

В настоящее время в микробиологии признано, что большинство микроорганизмов в естественных и искусственно созданных окружающих средах существует в виде структурированных, прикрепленных к поверхности сообществ - биопленок. В химическом отношении матрикс биопленки неоднороден и различается у разных микроорганизмов. Экстрацеллюлярный слой содержит до 40-95\% полисахаридов. Концентрация других химических компонентов очень сильно варьирует. Доля белков может составлять - до $60 \%$, липидов до $40 \%$ и нуклеиновых кислот до $20 \%$. Данные соединения находятся в гидратированном состоянии, так как 80-90\% объема биопленки занимает вода $[9,10]$.

Характерное свойство всех биопленок - их поразительная устойчивость к физическим и биохимическим воздействиям, включающая антибиотико-резистентность $[11,12]$, что требует изучение механизмов их разрушения, в том числе иммунной системой макроорганизма.

Многие микроорганизмы - возбудители гнойно-воспалительных заболеваний - синтезируют ферменты агрессии и инвазии. Взаимодействие их с иммунной системой макроорганизма может приводить к образованию абзимов с ферментативной активностью, присущей бактериям, которые могут принимать участие в патогенезе гнойно-воспалительных заболеваний [8].

Учитывая все вышесказанное, представляется важным оценить взаимодействие абзимов с субстратами, с помощью которых определяют ферментативную активность микроорганизмов, а также оценить их способность разрушать экзополимерный матрикс биопленок.

Цель. Определить роль протеолитической, ДНКазной, эскулиназной и уреазной активности абзимов в клинико-лабораторной картине и оценить их способность расщеплять экзополимерный матрикс биопленок у пациентов с хирургической инфекцией.

\section{Материал и методы}

Препараты иммуноглобулинов получали из сывороток крови пациентов с острыми и хроническими гнойно-воспалительными процессами (опытные группы), а также лиц с хирургической патологией без гнойно-воспалительных процессов и у доноров (контрольные группы). Все пациенты, составившие опытные и контрольную группы, прошли комплексное клиническое, инструментальное и лабораторное обследование.

В группу пациентов с хроническим остеомиелитом набор производился из пациентов, находившихся на лечении в Республиканском научно-практическом центре «Инфекция в хирургии» (РНПЦИХ). Группу с острыми гнойно-воспалительными процессами составили пациенты, находившиеся на лечении в хирургических отделениях Витебской областной клинической больницы (ВОКБ) и Витебской центральной городской клинической больницы (ВГЦКБ) по поводу абсцессов мягких тканей, флегмон, гнойных перитонитов. В группу 
пациентов с инфекционными заболеваниями челюстно-лицевой области включены пациенты одонтогенного и неодонтогенного происхождения, находившиеся на лечении в отделении челюстно-лицевой хирургии ВОКБ. Лица, страдающие от хронических инфицированных язв голеней, хронического фурункулеза, были включены в группу пациентов с хроническими гнойно-воспалительными процессами (набор проводился среди пациентов РНПЦИХ). Группы с холециститом и узловым зобом составили пациенты, находившиеся на момент забора крови в раннем послеоперационном периоде (1-е сутки) после холецистэктомии или тиреоидэктомии. Контрольную группу составили пациенты без гнойно-воспалительных процессов, прооперированные по поводу хирургической патологии без гнойных осложнений (грыжесечения, геморроидэктомия, флебэктомия), и доноры Витебской областной станции переливания крови. Распределение групп пациентов, исследованных на протеолитическую, ДНКазную и эскулиназную активность иммуноглобулинов, по полу и возрасту представлено в таблицах 1, 2 и 3.

При исследовании ферментативной активности иммуноглобулинов $\mathrm{G}$ в отношении матрикса биопленки пациенты были разделены по другому принципу на 4 группы: I группа пациенты с хроническими гнойно-воспалительными процессами (трофические язвы, пролежни); II - пациенты с распространенными острыми гнойно-воспалительными процессами (флегмоны мягких тканей); III - пациенты с локальными острыми гнойно-воспалительными процессами (абсцессы мягких тканей); IV - пациенты с тяжелой пневмонией. Распределение данных групп пациентов по полу и возрасту представлено в таблице 4.

Для исследования уреазной активности иммуноглобулинов было сформировано две группы. Первая группа - здоровые лица - ис-

Характеристика групा хирургических пациентов, исследованных

Таблица 1 на протеолитическую активность IgG, по полу и возрасту

\begin{tabular}{lcccc}
\hline \multicolumn{1}{c}{ Группа } & $\mathrm{n}$ & \multicolumn{2}{c}{ Пол } & \multicolumn{2}{c}{ М $\pm \mathrm{m}$} \\
Возраст, лет
\end{tabular}
Примечание: между группами достоверных отличий не выявлено (р>0,05).

Таблица 2

Характеристика групा хирургических пациентов, исследованных на ДНКазную активность IgG, по полу и возрасту

\begin{tabular}{lcccc}
\multicolumn{1}{c}{ Группа } & $\mathrm{n}$ & \multicolumn{2}{c}{ Пол } & \multicolumn{2}{c}{ М $\pm \mathrm{m}$} \\
Возраст, лет
\end{tabular}
Примечание: между группами достоверных отличий не выявлено $(\mathrm{p}>0,05)$.

Таблица 3

Характеристика групा хирургических пациентов, исследованных на эскулиназную активность IgG, по полу и возрасту

\begin{tabular}{|c|c|c|c|c|}
\hline \multirow[t]{2}{*}{ Группа } & \multirow[t]{2}{*}{$\mathrm{n}$} & \multicolumn{2}{|c|}{ Пол } & \multirow{2}{*}{$\begin{array}{c}\text { Мe (LQ-UQ), } \\
\text { Возраст, лет }\end{array}$} \\
\hline & & муж & жен & \\
\hline 1. Хронический остеомиелит & 6 & 5 & 1 & $47,5(32-58)$ \\
\hline 2. Острые гнойно-воспалительные процессы & 19 & 12 & 7 & $49(28-62)$ \\
\hline 3. Инфекция челюстно-лицевой области & 10 & 5 & 5 & $41(27,5-53,5)$ \\
\hline 4. Пациенты без гнойно-воспалительных процессов & 12 & 4 & 8 & $51,5(29-68)$ \\
\hline
\end{tabular}

Примечание: между группами достоверных отличий не выявлено $(\mathrm{p}>0,05)$. 
Характеристика групा хирургических пациентов, исследованных

Таблица 4 на способность IgG разрушать экзополимерный матрикс биопленки, по полу и возрасту

\begin{tabular}{|c|c|c|c|c|}
\hline \multirow[t]{2}{*}{ Группа } & \multirow[t]{2}{*}{$\mathrm{n}$} & \multicolumn{2}{|c|}{ Пол } & \multirow{2}{*}{$\begin{array}{r}\text { Me (LQ-UQ), } \\
\text { Возраст, лет }\end{array}$} \\
\hline & & муж & жен & \\
\hline 1. Хронические гнойно-воспалительные процессы & 10 & 6 & 4 & $69(53-75)$ \\
\hline 2. Распространенные острые гнойно-воспалительные процессы & 9 & 8 & 1 & $57(19-72)$ \\
\hline 3. Локальные острые гнойно-воспалительные процессы & 8 & 2 & 6 & $42(21-58)$ \\
\hline 4. Тяжелые пневмонии & 7 & 4 & 3 & $37(28-55)$ \\
\hline 5. Доноры & 22 & 14 & 8 & $40(28-50)$ \\
\hline
\end{tabular}

пользовалась в качестве контрольной и состояла из 11 обследованных Н. pylory (HР)-негативных пациентов. Набор в первую группу обследованных производился из пациентов, проходивших обследование по линии военкомата, и добровольцев на базе Витебской центральной районной поликлиники. Все пациенты (7 мужского и 4 женского пола, средний возраст $41,7 \pm 2,7)$ прошли комплексное клиническое, инструментальное и лабораторное обследование. Не было получено данных, указывающих на заболевания желудочно-кишечного тракта. Отсутствие Н. pylory было подтверждено морфологическим методом (6 человек), быстрым уреазным тестом (3 пациента) и методом ИФА по отсутствию IgG антител к антигенам НР в сыворотке крови (2 пациента).

Вторую группу составили НР-позитивные пациенты (всего 40, из них 21 мужского и 19

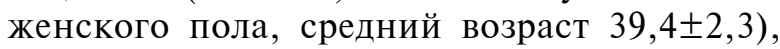
страдающие хроническим геликобактерным гастритом, дуоденитом либо гастродуоденитом. Все пациенты обследовались, получали лечение в гастроэнтерологическом отделении Витебской областной клинической больницы и прошли комплексное клиническое, инструментальное и лабораторное обследование. Забор крови для исследования производился до начала лечения.

Кровь забиралась натощак с 8 до 9 часов утра из локтевой вены, центрифугировалась со скоростью 1500 оборотов в минуту в течение 10 минут; сыворотка отбиралась, замораживалась и хранилась при $-25^{\circ} \mathrm{C}$.

Выделение иммуноглобулинов начинали в день забора сыворотки крови без предварительной заморозки. Очистка проводилась в несколько этапов риванол-сульфатным методом с использованием аффинной хроматографии на стафилококковом протеине А [13]. Поскольку подкласс 3 иммуноглобулинов $\mathrm{G}$ не связывается аффинно со стафилококковым протеином А, то полученный препарат содержал только IgG подклассов 1, 2 и 4.

До проведения анализов образцы иммуноглобулинов замораживали в жидком азоте с последующим хранением в нем или при $-25^{\circ} \mathrm{C}$ в холодильнике.

Проверка стерильности полученного материала осуществлялась выборочным посевом проб иммуноглобулинов на кровяной агар и сахарный бульон.

Определение протеолитической активности сывороток и IgG производилось по методу Эрлангера в нашей модификации [14] в реакциях с хромогенными субстратами протеолиза: бензоил-аргинин-р-нитроанилидом (БАПНА), лизин-р-нитроанилид (ЛНА) и ацетил-аспартатp-нитроанилидом (ААНА). Метод основан на том, что под воздействием трипсиноподобных протеаз происходит распад, например БАПНА, только в результате расщепления амидной (аналог пептидной) связи по аминокислотам аргинин-лизин. В результате реакции из молекулы субстрата образуется молекула р-нитроанилида, которая окрашивает раствор в желтый цвет, что делает возможным визуальный и инструментальный учет результатов.

Определение количества иммуноглобулинов в сыворотке производили с помощью набора для иммуноферментного анализа «IgG общий - ИФА - БЕСТ» (ЗАО «Вектор-БЕСТ», Россия).

Для определения доли, приходящейся на иммуноглобулины в общей сывороточной протеолитической активности, было выявлено количество иммуноглобулинов в 19 сыворотках пациентов с хроническими и острыми гнойновоспалительными процессами. Для определения вклада БАПНА-амидазной активности иммуноглобулинов в общую сывороточную активность вычислялась общая активность иммуноглобулинов в сыворотке умножением удельной активности иммуноглобулинов на их концентрацию в сыворотке. Далее вычислялась доля активности, приходящейся на иммуноглобулины в общей сывороточной активности, делением общей активности иммуноглобулинов на активность сыворотки.

Для определения эскулиназной активности IgG модифицирована методика определения 
эскулиназной активности микроорганизмов. Метод основан на том, что высвобождающийся при гидролизе эскулетин образует комплекс с цитратом железа, что приводит к изменению оптической плотности реакционной смеси. Уреазную активность IgG определяли по степени распада мочевины. Эластазная активность иммуноглобулинов определялась с использованием эластин-Конго красного [14]. Эластин-Конго красный (диаметр частиц 37-75 микрон) использовали в концентрации 0,8 г на 1 мл буфера как субстрат. При взаимодействии с эластазой последняя разрушает эластин, и Конго-красный переходит в раствор, изменяя его цвет с прозрачного на - красный (максимальный спектр поглошения 495 нм).

Определение ДНКазной активности $\mathrm{IgG}$ производилось двумя методами. Основной метод риванолового сгустка. Дополнительно, для подтверждения полученных результатов, был использован референс-метод, в котором для регистрации ДНКазной активности иммуноглобулинов применялся электрофорез в 1,2\% агарозном геле, а в качестве субстрата была использована ДНК плазмиды pBluescript [5].

Для оценки способности IgG расщеплять экзополимерный матрикс биопленки использован разработанный метод, основанный на использовании в качестве субстрата частиц матрикса биопленки диаметром 80-120 мкм, связанных с Конго-красным.

В стерильную чашку Петри с агаром Мюллера-Хинтона помещали стерильную инертную полимерную мембрану, фиксировали стеклянным грузом и вносили 0,5 мл взвеси $\mathrm{S}$. oralis плотностью 0,5 оптических единиц Мак-Фарланда $\left(1,5 \times 10^{8} \mathrm{KOE} /\right.$ мл $)$ и 5 мл стерильного изотонического раствора хлорида натрия. Инкубировали в течение 3 суток при температуре $37^{\circ} \mathrm{C}$. Мембрану извлекали, биопленку с мембраны смывали стерильным физиологическим раствором. К полученной суспензии добавляли в избытке $0,5 \%$ раствор Конго красного. Суспензию дважды отмывали стерильным изотоническим раствором хлорида натрия для удаления не связавшегося Конго красного с осаждением матрикса центрифугированием в режиме 1000 оборотов в мин (200 g) в течение 75 минут после каждой отмывки. Суспензию замораживали и хранили при $-25^{\circ} \mathrm{C}$ до использования.

Готовили рабочую суспензию экзополимерного матрикса биопленки. Для этого разводили размороженную суспензию матрикса стерильным изотоническим раствором хлорида натрия до 2,5 Еоп. Измерение оптической плотности производили на фотометре универсальном Ф300 при длине волны 492 нм и 0,15 мл суспензии матрикса в лунке 96-луночного планшета для ИФА. Далее 0,1 М раствором фосфатного буфера с рН 7,4 доводили оптическую плотность суспензии до 2 Еоп. В 1 мл рабочей суспензии содержалось 12,2 мг сухого матрикса, связанного с 0,1 мг Конго красного. В качестве консерванта в суспензию добавляли азид натрия в концентрации 2 мг/мл.

Реакцию ставили в пробирках типа эппендорф. Реакционная смесь состояла из 0,1 мл $\mathrm{IgG}$ в концентрации 1 мг/мл и 0,3 мл рабочей суспензии матрикса биопленки. После инкубации в течение 24 ч при $37^{\circ} \mathrm{C}$ реакционную смесь центрифугировали в режиме 10 мин при 10 тыс. оборотов в мин. (7930 g) на центрифуге MIKRO 120 (Hettich) для осаждения не разрушенных компонентов матрикса и переносили по 0,15 мл надосадка в лунки 96-луночного планшета для ИФА. Учет результатов реакции производили по увеличению оптической плотности надосадка на фотометре универсальном Ф300 при длине волны 492 нм. В качестве отрицательного контроля вместо раствора исследуемого препарата использовали стерильный изотонический раствор хлорида натрия. Для пересчета единиц оптической плотности в мкг/мл выделенного Конго красного использовалась формула (square root-Y модель):

$\mathrm{X}=\left(0,101+11,04 *\left[\mathrm{E}_{\text {оптическая пиотность пробы }}-\mathrm{E}_{\text {оптическая пюотность контроля }}\right]\right)^{2}$.

Статистическая обработка полученных результатов проводилась с помощью пакета прикладных таблиц "Statistica” (Version 10, StatSoft Inc., США). Перед использованием методов описательной статистики определяли тип распределения количественных признаков с использованием критерия Шапиро-Уилка. Для признаков с нормальным распределением рассчитывали среднюю арифметическую (М) и среднюю квадратичную ошибку (m). Для определения достоверности отличия групп использовался критерий Стьюдента. При распределении признака, отличном от нормального, вычисляли медиану (Ме), нижний 25-й (LQ) и верхний 75-й квартили (UQ). Данные представляли в виде Me (LQ-UQ). Для оценки статистической значимости между несвязанными группами применялся непараметрический критерий Манна-Уитни (U).

Для сравнения достоверности отличия процентного содержания в группах проб, обладающих определенными признаками, использовали точный критерий Фишера. Корреляции вычислялись методом Пирсона. При оценке степени согласованности направлений отклонений ин- 
дивидуальных значений от среднего показателя взаимосвязанных пар признаков использовалась корреляция знаков Фехнера. Для оценки силы влияния использовали однофакторный и многофакторный дисперсионный анализ.

\section{Результаты}

Протеолитическая активность иммуноглобулинов G. При изучении протеолитической активности установлено, что уровень БАПНАамидазной активности иммуноглобулинов в группах пациентов с гнойными процессами был достоверно выше, чем у пациентов без хирургической инфекции или здоровых доноров (таблица 5), причем достоверных отличий между группами в зависимости от остроты и локализации гнойного процесса выявлено не было ( $>>0,05)$.

При изучении связи БАПНА-амидазной активности с клиническими данными была выявлена отрицательная корреляция между уровнем активности иммуноглобулинов и временем пребывания пациента в стационаре $(\mathrm{r}=-0,43 ; \mathrm{n}=21 ; \mathrm{p}<0,05)$. Также обнаружена положительная корреляция между наличием у пациентов высокого уровня БАПНА-амидазной активности IgG и повышением СОЭ ( $\mathrm{r}=0,53$; $\mathrm{n}=21 ; \mathrm{p}=0,01)$.

При оценке группы пациентов с острыми гнойно-воспалительными процессами (включая пациентов с гнойно-воспалительными заболеваниями челюстно-лицевой области) методом однофакторного дисперсионного анализа выявлено, что на уровень БАПНА-амидазной активности иммуноглобулинов класса $\mathrm{G}$ оказывали влияние следующих факторы: абсолютный уровень лейкоцитов - 3\% (n=38, $\mathrm{p}<0,05)$, абсолютный уровень лимфоцитов $-2,9 \%(\mathrm{n}=38$, $\mathrm{p}<0,05)$, абсолютный уровень моноцитов $-3,3 \%$ $(\mathrm{n}=38, \mathrm{p}<0,01)$, абсолютный уровень эозинофилов $-8,3 \%(\mathrm{n}=38, \mathrm{p}<0,01)$.

При оценке ЛНА-амидазной активности иммуноглобулинов оказалось, что ее уровень у пациентов с гнойно-воспалительными процессами $(0,325 ; 0,149-0,996$ пкат, $n=21)$ не отличался достоверно ( $p>0,05)$ от уровня актив- ности у доноров (0,281; 0,259-0,358 пкат, $\mathrm{n}=16)$. Также и уровень АПНА-амидазной активности иммуноглобулинов при гнойно-воспалительных процессах (0; 0-0,86 пкат, n=14) не отличался достоверно от уровня активности у доноров (0; 0-0,06 пкат, $\mathrm{n}=16$ )

Уровень ацетил-аспартат-р-нитроанилидамидазной активности иммуноглобулинов у пациентов с гнойно-воспалительными процессами был достоверно ( $<<0,0001)$ ниже $(0 ; 0-0,083$ пкат, $\mathrm{n}=21)$, чем в группе доноров $(0,122 ; 0,083-0,149$ пкат, $\mathrm{n}=16$ ).

У пациентов с хирургической инфекцией обнаружены сильные $(r>0,6)$ достоверные $(\mathrm{p}<0,01)$ корреляции между всеми парами активностей, за исключением АПНА-амидазной, которая не коррелировала с другими видами протеолитической активности.

Эластазная активность определена у препаратов IgG 12 пациентов с гнойно-воспалительными процессами. При этом ее уровень достоверно не отличался от контроля.

Выявлено, что доля трипсиноподобной активности, приходящаяся на иммуноглобулины в общей сывороточной протеолитической активности, оказалась значительной. У пациентов с острыми гнойными процессами эта доля оказалась выше, чем у пациентов с хроническим остеомиелитом, но это отличие было не достоверным ( $>00,05)$.

Всего исследованы пары иммуноглобулин-сыворотки, полученные от 12 пациентов с хроническим остеомиелитом и 7 пациентов с острой хирургической инфекцией. Установлено (таблица 6), что доля иммуноглобулинов в общей сывороточной протеолитической активности у пациентов с хирургической инфекцией оказалась весьма значительной и составила у лиц с хроническим остеомиелитом: медиана $11,64 \%, 25-75$ процентили - 6,19\% и 46,86\%; а у пациентов с острыми гнойно-воспалительными процессами: медиана - 16,31\%, 25-75 процентили $-7,84 \%$ и $96,8 \%$.

Ферментативная активность иммуноглобулинов $\mathbf{G}$ против матрикса биопленки. В результате проведенного исследования установлено, что препараты иммуноглобулинов доноров и

БАПНА-амидазная активность IgG

Таблица 5

\begin{tabular}{lccc}
\hline \multicolumn{1}{c}{ Группа } & $\mathrm{n}$ & $\mathrm{Me}(\mathrm{LQ}-\mathrm{UQ})$ пкат & $\begin{array}{c}\text { Достоверность } \\
\text { отличий }\end{array}$ \\
\hline 1. Хронический остеомиелит & & $0,27(0-0,524)$ & $\mathrm{p}_{1-4}<0,05$ \\
2. Острые гнойно-воспалительные процессы & 30 & $0,281(0,148-0,453)$ & $\mathrm{p}_{1-5}<0,01$ \\
3. Инфекция челюстно-лицевой области & 33 & $0,226(0,149-0,361)$ & $\mathrm{p}_{2-4}<0,01$ \\
4. Пациенты без гнойно-воспалительных процессов & 20 & $0,168(0,062-0,237)$ & $\mathrm{p}_{2-5}<0,001$ \\
5. Доноры & 16 & $0,056(0,006-0,105)$ & $\mathrm{p}_{3-5}<0,001$ \\
Примечание: достоверных отличий между остальными группами не выявлено (p>0,05). & $\mathrm{p}_{3-4}<0,05$ \\
\hline
\end{tabular}


Доля БАПНА-амидазной активности IgG в общей сывороточной активности

\begin{tabular}{|c|c|c|c|c|}
\hline Группа & $\begin{array}{c}\text { Общая } \\
\text { сывороточная } \\
\text { активность, } \\
\text { пкат/мл }\end{array}$ & $\begin{array}{c}\text { Удельная } \\
\text { активность } \\
\text { IgG, пкат/мг }\end{array}$ & $\begin{array}{c}\text { Общая } \\
\text { активность } \\
\text { IgG } \\
\text { сыворотки, } \\
\text { пкат/мл } \\
\end{array}$ & $\begin{array}{c}\text { Доля } \\
\text { активности } \\
\text { IgG в общей } \\
\text { сывороточной } \\
\text { активности, \% } \\
\end{array}$ \\
\hline Хронический остеоми & $\begin{array}{c}39,6 \\
(18,2-73,2)\end{array}$ & $\begin{array}{c}0,526 \\
(0,252-0,699)\end{array}$ & $\begin{array}{c}6,67 \\
(3,54-14,32)\end{array}$ & $\begin{array}{c}11,64 \\
(6,19-46,86)\end{array}$ \\
\hline Острые гнойно-воспалительные процессы & $\begin{array}{c}16,3 \\
(5-32,1)\end{array}$ & $\begin{array}{c}0,515 \\
(0,13-0,755)\end{array}$ & $\begin{array}{c}5,92 \\
(1,722-12,33)\end{array}$ & $\begin{array}{c}16,31 \\
(7,84-96,8) \\
\end{array}$ \\
\hline
\end{tabular}

Примечание: достоверных отличий между группами не выявлено.

пациентов с хирургической инфекцией способны расщеплять экзополимерный матрикс биопленки S. aureus.

Максимальная активность IgG наблюдалась в группе пациентов с тяжелыми пневмониями - 0,111 $(0,032-0,227)$ мкг/мл, где она была достоверно выше, чем в группах пациентов с хроническими $(0,032(0-0,071)$ мкг/мл) и распространенными гнойно-воспалительными процессами $(0(0-, 054)$ мкг/мл). В целом активность IgG была не очень высокая. Результаты представлены в таблице 7. Не обнаружено корреляций способности IgG к расщеплению матрикса биопленки S. aureus с клинико-лабораторными проявлениями заболеваний. Выявлено, что у IgG пациентов с инфекционным процессом, у которых был выделен в качестве возбудителя S. aureus, уровень способности разрушать матрикс биопленки (0 $(0-0,028)$ мг/мл) был достоверно $(\mathrm{p}=0,009)$ ниже, чем у IgG пациентов, у которых была выделена другая микрофлора - 0,04 (0,018-0,09) мг/мл.
ДНКазная активность иммуноглобулинов G. Исследование препаратов IgG было выполнено на базе Лаборатории ферментов репарации НИИ химической биологии и фундаментальной медицины (Новосибирск) в рамках совместных исследований [5]. Параллельно двумя методами ДНКазная активность была определена у 15 препаратов IgG, выделенных от пациентов с хирургической инфекцией. Между полученными результатами наблюдалась сильная корреляция: $\mathrm{r}=0,91, \mathrm{p}<0,01$.

Наиболее высокий уровень ДНКазной активности иммуноглобулинов $\mathrm{G}$ (таблица 8) выявлен в группе лиц с острыми гнойными процессами и достоверно превышал уровень в контрольной группе $(33,84 \pm 5,12$ ЕОП; n=38; $\mathrm{p}<0,01)$. Близкий уровень активности иммуноглобулинов наблюдался в группе лиц с хроническим остеомиелитом $(31,66 \pm 6,022$ ЕОП; $\mathrm{n}=32 ; \mathrm{p}<0,05)$.

В группе лиц с инфекцией челюстно-лицевой области выявлен невысокий уровень

Способность IgG разрушать экзополимерный матрикс биопленки S. aureus

Таблица 7

\begin{tabular}{lccc}
\hline \multicolumn{1}{c}{ Группа } & $\mathrm{n}$ & $\mathrm{Me}(\mathrm{LQ}-\mathrm{UQ})$, & $\begin{array}{c}\text { Достоверность } \\
\text { окг/мл }\end{array}$ \\
\hline 1. Хроничийеские гнойно-воспалительные процессы & 10 & $0,032(0-0,071)$ & $\mathrm{p}_{1-4}<0,05$ \\
2. Распространенные острые гнойно-воспалительные процессы & 9 & $0(0-0,054)$ & $\mathrm{p}_{2-4}^{<0,01}$ \\
3. Локальные острые гнойно-воспалительные процессы & 8 & $0,036(0-0,071)$ & \\
4. Тяжелые пневмонии & 7 & $0,111(0,032-0,227)$ \\
5. Доноры & 22 & $0,04(0-0,118)$ \\
\hline Примечание: между остальными группами достоверных отличий не выявлено (р>0,05).
\end{tabular}

Средний уровень ДНКазной активности IgG

Таблица 8

\begin{tabular}{lccc}
\hline \multicolumn{1}{c}{ Группа } & $\mathrm{n}$ & $\begin{array}{c}\text { ДНКазная активность Ig } \\
\mathrm{M} \pm \mathrm{m}, \mathrm{E}_{\text {оп }}\end{array}$ & $\begin{array}{c}\text { Достоверность } \\
\text { отличий }\end{array}$ \\
\hline 1. Хронический остеомиелит & 32 & $31,66 \pm 6,022$ & $\mathrm{p}_{1-3}<0,05$ \\
2. Острые гнойно-воспалительные процессы & 38 & $33,84 \pm 5,12$ & $\mathrm{p}_{1-7}<0,05$ \\
3. Инфекция челюстно-лицевой области & 27 & $14,04 \pm 2,65$ & $\mathrm{p}_{2-3}^{<0,01}$ \\
4. Хронические гнойно-воспалительные процессы & 7 & $25 \pm 4,88$ & $\mathrm{p}_{2-7}^{<0,01}$ \\
5. Холецистит & 12 & $20,17 \pm 3,55$ & $\mathrm{p}_{4-7}<0,05$ \\
6. Узловой зоб & 17 & $18,65 \pm 3,89$ & \\
7. Пациенты без гнойно-воспалительных процессов & 17 & $10,94 \pm 3,42$ & \\
Примечание: между остальными группами достоверных отличий не выявлено (р>0,05).
\end{tabular}


ДНКазной активности иммуноглобулинов $(14,04 \pm 2,65$ ЕОП; $n=27)$. Он оказался достоверно ниже, чем в группе пациентов с хроническим остеомиелитом и в группе пациентов с острой гнойной патологией $(\mathrm{p}<0,05$ и $\mathrm{p}<0,01$ соответственно). Уровень ДНКазной активности в контрольной группе был низок, но отличался от нуля $(10,94 \pm 3,42$ ЕОП, $\mathrm{n}=17)$. В группах пациентов с хроническим холециститом и узловым зобом уровень ДНКазной активности не отличался достоверно от контрольной группы.

Количество лиц с достоверно положительной ДНКазной активностью $\operatorname{IgG}$ (т.е. такой активностью, уровень которой достоверно превышает уровень спонтанного распада субстрата в контрольных пробах) в группе лиц с узловым зобом было достоверно выше $(\mathrm{p}<0,05)$ в сравнении с контрольной группой (9 из 16 и 3 из 17 соответственно). Для остальных групп этот показатель подтверждал результаты, полученные при исследовании среднего уровня ДНКазной активности иммуноглобулинов класса G.

При оценке зависимости уровня ДНКазной активности от вида микроорганизма, вызвавшего воспалительный процесс, было выявлено: средний уровень активности у пациентов, от которых были выделены бактерии, продуцирующие значительное количество нуклеаз (S. aureus, P. aeruginosa, E. coli, Proteus spp), был достоверно выше, чем у пациентов с микроорганизмами, не продуцирующими значительного количества нуклеаз - коагулазоотрицательными стафилококками, $30,7 \pm 4,24$ и 11,5 $\pm 5,27$ ЕОП соответственно, $\mathrm{p}<0,02$. Частота встречаемости лиц с достоверно положительной ДНКазной активностью IgG была также достоверно выше среди пациентов с микроорганизмами, продуцирующими значительное количество нуклеаз, 19 из 39 и 2 из 15, p<0,01 (таблица 9).

Помимо этого, выявлена корреляция знаков Фехнера средней силы между наличием у препарата иммуноглобулина $\mathrm{G}$, выделенного от пациента, достоверной ДНКазной активности и золотистым стафилококком в качестве этиологического фактора $(\mathrm{r}=0,31 ; \mathrm{p}<0,05 ; \mathrm{n}=54)$.

По данным однофакторного дисперсионного анализа сила влияния S. aureus в качестве этиологического фактора на уровень ДНКазной активности IgG составила $11,2 \%(\mathrm{n}=52, \mathrm{p}<0,05)$, а для лиц с острой инфекцией (включая ин- фекцию челюстно-лицевой области) - 14,6\% $(\mathrm{n}=30, \mathrm{p}<0,05)$.

Выявлено у пациентов с хирургической инфекцией наличие корреляций между уровнем ДНКазной активности иммуноглобулинов класca $\mathrm{G}$ и показателями иммунитета: абсолютным количеством лейкоцитов в крови $(\mathrm{r}=0,43 ; \mathrm{n}=57$; p $<0,001)$; абсолютным количеством юных и палочкоядерных форм нейтрофилов $(\mathrm{r}=0,43 ; \mathrm{n}=49$; $\mathrm{p}<0,005)$. Для группы пациентов с острыми гнойными заболеваниями обнаружены следующие корреляции: между повышенной температурой и наличием IgG с достоверно положительной ДНКазной активностью $(\mathrm{r}=0,59 ; \mathrm{n}=17$; $\mathrm{p}<0,01)$; абсолютным количеством лейкоцитов и средним уровнем ДНКазной активности $\mathrm{IgG}$ $(\mathrm{r}=0,62 ; \mathrm{n}=30 ; \mathrm{p}<0,0002)$; абсолютным количеством моноцитов и средним уровнем ДНКазной активности $\operatorname{IgG}(\mathrm{r}=0,42 ; \mathrm{n}=30 ; \mathrm{p}<0,05)$.

При использовании однофакторного дисперсионного анализа для всей совокупности пациентов с хирургической инфекцией выявлены следующие клинико-лабораторные данные, влияющие на уровень ДНКазной активности иммуноглобулинов: наличие у пациентов повышенного количества незрелых форм нейтрофилов в крови $-16,12 \%(\mathrm{n}=49, \mathrm{p}<0,005)$, повышенный уровень лейкоцитов $-5,8 \%(\mathrm{n}=57$, $\mathrm{p}<0,05)$. Для группы пациентов с острыми гнойными процессами: температура тела пациента $14,3 \%(\mathrm{n}=10, \mathrm{p}<0,01)$, повышенный уровень абсолютного числа лейкоцитов $-12,1 \%(\mathrm{n}=31$, $\mathrm{p}<0,01)$, наличие у пациента повышенного абсолютного уровня юных и палочкоядерных форм нейтрофилов $-23,3 \%(\mathrm{n}=30, \mathrm{p}<0,01)$, повышенный абсолютный уровень моноцитов $13,5 \%(n=30, p<0,05)$, наличие у пациента повышенного уровня СОЭ - 25,9\% $(n=18, p<0,05)$. Для группы пациентов с инфекцией челюстнолицевой области: длительность пребывания пациента в стационаре до выписки - 27,3\% $(\mathrm{n}=27, \mathrm{p}<0,01)$, наличие у пациента синдрома системного воспалительного ответа $-21,7 \%$ $(\mathrm{n}=27, \mathrm{p}<0,05)$.

Эскулиназная активность IgG. Эскулиназная или Я-глюкозидазная активность встречается у некоторых видов микроорганизмов-возбудителей гнойно-воспалительных заболеваний, таких как Enterococcus faecalis, Enterococcus faecium, Klebsiella oxytoca, Klebsiella

Таблица 9

Зависимость ДНКазной активности IgG от вида возбудителя гнойного процесса

\begin{tabular}{lccccc}
\hline $\begin{array}{c}\text { Группа (по наличию у } \\
\text { возбудителя ДНКазной } \\
\text { активности) }\end{array}$ & $\mathrm{n}$ & $\begin{array}{c}\text { Активность Ig } \\
\mathrm{M} \pm \mathrm{m}, \mathrm{E}_{\text {оп }}\end{array}$ & $\begin{array}{c}\text { Достоверность } \\
\text { отличий }\end{array}$ & $\begin{array}{c}\mathrm{Ig} \text { с достоверно } \\
\text { положительной } \\
\text { активностью }\end{array}$ & $\begin{array}{c}\text { Достоверность } \\
\text { отличий }\end{array}$ \\
\hline Высокая активность & 39 & $30,7 \pm 4,24$ & $\mathrm{p}<0,02$ & $19(48,7 \%)$ & $\mathrm{p}<0,05$ \\
Низкая активность & 15 & $11,5 \pm 5,27$ & & $2(13,3 \%)$ & \\
\hline
\end{tabular}


pneumoniae pneumoniae, Citrobacter amalonaticus, Enterobacter aerogenes, Enterobacter intermedius, Streptococcus angiosus, S. lentus, S. sciuri, S. gallinarium, но отсутствует у Staphylococcus aureus, Streptococcus pyogenes, E.coli u Pseudomonas spp. Ранее описан гидролиз кумариновых эфиров, индуцированный препаратами моноклональных иммуноглобулинов [15], но эскулиназная активность у поликлональных IgG выявлена впервые.

При исследовании эскулиназной активности иммуноглобулинов класса $\mathrm{G}$ (таблица 10) было выявлено, что у лиц с острой гнойной хирургической инфекцией ее уровень (120 (63249) ЕОП) был достоверно выше, чем в группе пациентов хроническим остеомиелитом $(42,5$ (32-62) ЕОП), группе пациентов с инфекцией челюстно-лицевой области (37 (9-59) ЕОП) и в группе лиц без гнойных процессов (54,5 (46103) ЕОП).

Уреазная активность иммуноглобулинов класса G. В результате исследования уреазной активности $\mathrm{IgG}$ было установлено, что средний ее уровень у НР-позитивных пациентов был достоверно выше, чем в группе НРнегативных лиц (соответственно 7,259 $\pm 1,523$ пкат и $1,427 \pm 0,322$ пкат, $\mathrm{p}<0,05)$. Кроме того, частота лиц с достоверно положительным уровнем уреазной активности была выше в группе НР-позитивных лиц - 35\% (14 из 40) и 0\% (0 из 11), $<<0,05$. Установлена корреляционная зависимость средней силы между уровнем уреазной активности $\operatorname{IgG}$ и уровнем $\mathrm{IgG}$ антител к НР в выделенной фракции $(\mathrm{r}=0,62 ; \mathrm{p}<0,05)$.

\section{Обсуждение}

У выделенных препаратов иммуноглобулинов произведено определение протеолитической активности в реакциях с тремя хромогенными субстратами - бензоил-аргининp-нитроанилином, лизин-р-нитроанилином и ацетил-аспартат-р-нитроанилином. Несмотря на сходство хромогенных субстратов, отсутствуют корреляции уровней протеолитической активности препаратов иммуноглобулинов, определенных в реакциях с различными субстратами. БАПНА является стандартным субстратом для определения трипсина, и в то же время многие возбудители хирургической инфекции, такие как грамотрицательные неферментирующие микроорганизмы и энтеробактерии способны ее расщеплять. В то же время стафилококки не показывают трипсиноподобной активности на данном субстрате, обладая при этом широким спектром протеолитической активности, например эластазной. Образование абзимов на протеолитические ферменты микроорганизмов из-за их широкого спектра возможных протеаз и одновременно на ферменты, расщепляющие белки макроорганизма, при совокупном влиянии многих разнонаправленных факторов приводит к очень сложному профилю возможной активности каталитических антител. Наличие БАПНА-амидазной активности иммуноглобулинов у пациентов без инфекционного процесса может быть связано с влиянием сапрофитной микрофлоры, а также с возникновением активности под влиянием факторов неинфекционной природы, например уровням трипсина, продуцируемого поджелудочной железой. В результате не удалось выявить связи между уровнем БАПНА-амидазной активности иммуноглобулинов и видом микроорганизма, вызвавшего инфекционный процесс.

По результатам определения ЛПАамидазной и ААНА-амидазной активностей не выявлено достоверных отличий между группой пациентов с гнойно-воспалительными процессами и здоровыми донорами. При исследовании БАПНА-амидазной активности иммуноглобулинов установлено, что у лиц с острыми и хроническими гнойно-воспалительными процессами уровень активности достоверно выше, чем у иммуноглобулинов здоровых доноров и пациентов без гнойных процессов.

При проведении исследования удалось установить, что у пациентов с хирургической инфекцией выявлен значительный средний вклад абзимной активности $(11,64 \%$ и $16,31 \%$ при хронических и острых гнойно-воспалительных процессах соответственно) в общую протеолитическую активность сыворотки, а в четырех парах сыворотки-иммуноглобулина расчетная доля активности иммуноглобулина приближалась к $100 \%$. Очевидно, что вклад иммуноглобулинов в общую сывороточную протеолитическую ак-

Уровень эскулиназной активности IgG

\begin{tabular}{lccc}
\hline \multicolumn{1}{c}{ Группа } & $\mathrm{n}$ & $\mathrm{Me}(\mathrm{LQ}-\mathrm{UQ}), \mathrm{E}_{\text {оп }}$ & $\begin{array}{c}\text { Достоверность } \\
\text { отличий }\end{array}$ \\
\hline 1. Хронический остеомиелит & 6 & $42,5(32-62)$ & $\mathrm{p}_{1-2}<0,05$ \\
2. Острые гнойно-воспалительные процессы & 19 & $120(63-249)$ & $\mathrm{p}_{2-3}^{<}<0,01$ \\
3. Инфекция челюстно-лицевой области & 10 & $37(9-59)$ & $\mathrm{p}_{2-4}^{<0,05}$ \\
4. Пациенты без гнойно-воспалительных процессов & 12 & $54,5(46-103)$ & \\
\hline
\end{tabular}


тивность является существенным, что может играть значимую роль в патогенезе гнойно-воспалительных заболеваний.

Показано, что каталитические антитела на ферменты микроорганизмов образуются не всегда. Так, не обнаружено у IgG, выделенных от пациентов с гнойно-воспалительными процессами, эластазной активности. В то же время такие значимые возбудители хирургической инфекции, как золотистый стафилококк, и синегнойная палочка, обладают выраженной эластазной активностью.

Ферментативная активность иммуноглобулинов $\mathrm{G}$ против матрикса биопленки, учитывая ее строение [10], вероятно, связана с расщеплением гиалуроновой кислоты матрикса за счет гиалуронидазной активности $\mathrm{IgG}$, ДНКазной активности IgG за счет расщепления ДНК матрикса и в меньшей степени протеолитической активности.

У пациентов с гнойно-воспалительными заболеваниями по сравнению с пациентами без гнойных процессов показано достоверное повышение уровня ДНКазной активности иммуноглобулинов класса G. Выявлено, что уровень ДНКазной активности иммуноглобулинов класса $\mathrm{G}$ имеет коррелятивные связи с клинико-лабораторными проявлениями заболевания и показателями активности иммунной системы. Обнаружено наличие связи между видом микроорганизма, вызвавшего патологический процесс, и уровнем абзимной активности иммуноглобулинов. Так, у пациентов, от которых были высеяны золотистый стафилококк, псевдомонады, клебсиеллы, протеи, кишечная палочка, ДНКазная активность иммуноглобулинов $\mathrm{G}$ была достоверно выше, чем у пациентов, гнойно-воспалительный процесс у которых был вызван коагулазоотрицательными стафилококками.

При исследовании уреазной активности IgG у НР-позитивных пациентов получены прямые доказательства влияния на абзимную активность инфекционного агента, так как ферменты с уреазной активностью не продуцируются макроорганизмом.

\section{Выводы}

У пациентов с хирургической инфекцией и у здоровых доноров обнаружена протеолитическая абзимная активность в реакциях с бензоил-аргинин-р-нитроанилидом, лизин-р-нитроанилидом, аргинин-пролинp-нитроанилидом и ацетил-аспартат-рнитроанилидом. Показано наличие достоверно повышенного уровня БАПНА-амидазной активности иммуноглобулинов класса $\mathrm{G}$ у хи- рургических пациентов с гнойно-воспалительными процессами в сравнении с пациентами без гнойных осложнений. Выявлено, что между БАПНА-амидазной и другими видами протеолитической активности иммуноглобулинов пациентов с хирургической инфекцией отсутствует корреляция, что может свидетельствовать о разном происхождении БАПНА-амидазной, ЛНА-амидазной, АПНА-амидазной и ААНАамидазной активностей.

Впервые выявлено наличие у препаратов поликлональных иммуноглобулинов класса $\mathrm{G}$ эскулиназной активности и способности $\mathrm{IgG}$ разрушать бактериальную биопленку.

У пациентов с гнойно-воспалительными заболеваниями по сравнению с пациентами без гнойных процессов показано достоверное повышение уровня ДНКазной активности иммуноглобулинов класса G. Установлена взаимосвязь каталитической активности иммуноглобулинов с видом микроорганизма, вызвавшего патологический процесс.

\section{ЛИТЕРАТУРА}

1. Косинец АН, Косинец ВА, Стручков ЮВ. Инфекция в хирургии: учебник. Минск, РБ: Бел Энцыкл ім П Броу̃кі; 2012. 496 с.

2. Генералов ИИ. Абзимная активность иммуноглобулинов. Витебск, РБ: ВГМУ; 2000. 152 с.

3. Leatnerbarrow RJ. Designer catalytic antibodies. $\mathrm{Na}$ ture. 1989 Mar 16;338:206-207. doi:10.1038/338206a0.

4. Keinan E. Catalytic Antibodies. Germany: VCHWiley press; 2005. $586 \mathrm{p}$.

5. Одинцова ЕС, Пархоменко ТА, Кундер ЕВ, Окулич ВК, Жильцов ИВ, Сенькович СА, и др. ДНКгидролизующие $\operatorname{IgG}$ антитела из крови пациентов бактериальными инфекционными заболеваниями. Иммунопатология Аллергология Инфектология. 2006;(2):23-31.

6. Brown EL, Nishiyama Y, Dunkle JW, Aggarwal S, Planque S, Watanabe K, et al. Constitutive production of catalytic antibodies to a Staphylococcus aureus virulence factor and effect of infection. $J$ Biol Chem. 2012 Mar 23;287(13):9940-51. doi: 10.1074/jbc. M111.330043.

7. Paul S, Planque SA, Nishiyama Y, Hanson CV, Massey RJ. Nature and nurture of catalytic antibodies. Adv Exp Med Biol. 2012;750:56-75. doi: 10.1007/9781-4614-3461-0 5.

8. Jerne NK. Towards a network theory of the immune system. Ann Immunol (Paris). 1974 Jan;125C(1-2):373-89.

9. Davey ME, O'toole GA. Microbial biofilms: from ecology to molecular genetics. Microbiol Mol Biol Rev. 2000 Dec;64(4):847-67.

10. Dongari-Bagtzoglou A. Pathogenesis of mucosal biofilm infections: challenges and progress. Expert Rev Anti Infect Ther. 2008 Apr;6(2):201-8. doi: 10.1586/14787210.6.2.201.

11. Чеботарь ИВ, Маянский АН, Кончакова ЕД, Лазарева АВ, Чистякова ВП. Антибиотикорезистентность биопленочных бактерий. Клин Микробиология и Антимикроб Химиотерапия. 2012;14(1):51-58. 
12. Мальцев СВ, Мансурова ГШ. Что такое биопленка. Природная Медицина: Клинические Исследования. 2013;1:86-89.

13. Фримель Г, ред. Иммунологические методы: монография. Тарасова АП, пер. с нем. Москва, СССР: Медицина; 1987. 472 с.

14. Окулич ВК, Сенькович СА, Плотников ФВ, Кабанова АА, Мацкевич ЕЛ. Роль абзимной активности иммуноглобулинов класса $\mathrm{G}$ у пациентов с хирургической инфекцией. Хирургия Восточная $E_{\boldsymbol{B}}$ pona. 2013;(2):6-14.

15. Pollack SJ, Jacobs JW, Schultz PG. Selective chemical catalysis by an antibody. Science. 1986 Dec 19;234(4783):1570-73.

\section{REFERENCES}

1. Kosinets AN, Kosinets VA, Struchkov IuV. Infektsiia $\mathrm{v}$ khirurgii [Infection in Surgery]: uchebnik. Minsk, RB: Bel Entsykl im P Broki; 2012. 496 s.

2.Generalov II. Abzimnaia aktivnost' immunoglobulinov [Abzyme activity immunoglobulin]. Vitebsk, RB: VGMU; 2000. 152 p.

3.Leatnerbarrow RJ. Designer catalytic antibodies. $\mathrm{Na}$ ture. 1989 Mar 16;338:206-207. doi:10.1038/338206a0.

4.Keinan E. Catalytic Antibodies. Germany: VCHWiley press; 2005. 586 p.

5.Odintsova ES, Parkhomenko TA, Kunder EV, Okulich VK, Zhil'tsov IV, Sen'kovich SA, i dr. DNKgidrolizuiushchie IgG antitela iz krovi patsientov bakterial'nymi infektsionnymi zabolevaniiami [DNAhydrolyzing antibody $\mathrm{IgG}$ from the blood of patients with bacterial infectious diseases]. Immunopatologiia Allergologiia Infektologiia. 2006;(2):23-31.

6.Brown EL, Nishiyama Y, Dunkle JW, Aggarwal $\mathrm{S}$, Planque S, Watanabe $\mathrm{K}$, et al. Constitutive production of catalytic antibodies to a Staphylococcus

\section{Адрес для корреспонденции}

210023, Республика Беларусь,

г. Витебск, пр. Фрунзе, д. 27,

УО «Витебский государственный

медицинский университет»,

кафедра клинической микробиологии,

тел. раб.: +375 212 37-06-12,

e-mail: vokul@mail.ru,

Окулич Виталий Константинович

\section{Сведения об авторах}

Окулич В.К., к.м.н., доцент кафедры клинической микробиологии УО «Витебский государственный медицинский университет». aureus virulence factor and effect of infection. $J$ Biol Chem. 2012 Mar 23;287(13):9940-51. doi: 10.1074/jbc. M111.330043.

7. Paul S, Planque SA, Nishiyama Y, Hanson CV, Massey RJ. Nature and nurture of catalytic antibodies. Adv Exp Med Biol. 2012;750:56-75. doi: 10.1007/9781-4614-3461-0_5.

8. Jerne NK. Towards a network theory of the immune system. Ann Immunol (Paris). 1974 Jan;125C(1-2):373-89.

9. Davey ME, O'toole GA. Microbial biofilms: from ecology to molecular genetics. Microbiol Mol Biol Rev. 2000 Dec;64(4):847-67.

10. Dongari-Bagtzoglou A. Pathogenesis of mucosal biofilm infections: challenges and progress. $E x-$ pert Rev Anti Infect Ther. 2008 Apr;6(2):201-8. doi: 10.1586/14787210.6.2.201.

11. Chebotar' IV, Maianskii AN, Konchakova ED, Lazareva AV, Chistiakova VP. Antibiotikorezistentnost' bioplenochnykh bakterii [Antibiotic resistance of biofilm bacteria]. Klin Mikrobiologiia i Antimikrob Khimioterapiia. 2012;14(1):51-58.

12. Mal'tsev SV, Mansurova GSh. Chto takoe bioplenka [What is biofilm]. Prirodnaia Meditsina: Klinicheskie Issledovaniia. 2013;1:86-89.

13. Frimel G, red. Immunologicheskie metody [Immunological methods]: monografiia. Tarasova AP, per. s nem. Moscow, SSSR: Meditsina; 1987. 472 p.

14. Okulich VK, Sen'kovich SA, Plotnikov FV, Kabanova AA, Matskevich EL. Rol' abzimnoi aktivnosti immunoglobulinov klassa $\mathrm{G} u$ patsientov $\mathrm{s}$ khirurgicheskoi infektsiei [Role of abzyme activity of immunoglobulin $G$ in patients with surgical infection. Khirurgiia Vostochnaia Evropa. 2013;(2):6-14.

15. Pollack SJ, Jacobs JW, Schultz PG. Selective chemical catalysis by an antibody. Science. 1986 Dec 19;234(4783):1570-73.

\section{Address for correspondence}

210023, Republic of Belarus,

Vitebsk, pr. Frunze, 27, EE «Vitebsk

State Medical University»,

department of clinical microbiology.

Tel.: +375 21206.12 .37

E-mail: vokul@mail.ru

Okulich Vitaly Konstantinovich

\section{Information about the authors}

Okulich V.K. PhD, Ass. Professor of department of clinical microbiology, EE «Vitebsk State Medical University». 